\title{
Effect of Indaziflam Application and Soil Manipulations on Pecan Evapotranspiration and Gas Exchange Parameters
}

\author{
Amir M. González-Delgado ${ }^{1}$ and Manoj K. Shukla \\ Plant and Environmental Sciences Department, New Mexico State \\ University, P.O. Box 30003 MSC-3Q, Skeen Hall, Las Cruces, NM 88003- \\ 8003
}

\section{Brian Schutte \\ Department of Entomology, Plant Pathology and Weed Science, New Mexico State University, P.O. Box 30003 MSC-3AE, Skeen Hall, Las Cruces, NM 88003-8003}

Additional index words. irrigation, water stress, photosynthetic rate, herbicide, phytotoxicity, preferential flow

\begin{abstract}
Appropriate soil management practices and correct use of agrochemicals for crop protection are essential to alleviate stresses that affect the quality and yield of pecans [Carya illinoinensis (Wangenh.) K. Koch]. A greenhouse study was conducted to evaluate the effect of soil surface manipulation and indaziflam application on evapotranspiration (ET) and gas exchange parameters of pecan trees, and phytotoxicity effects of indaziflam on pecan trees. Trees were planted in large pots with a homogeneous porous media (HM), including the controls (C), preferential flow channels open at the soil surface (PF), and preferential flow channels with surface soil manually tilled to $5 \mathrm{~cm}$ depth [shallow tillage (ST)]. Trees with HM, PF, and ST were treated with $50 \mathrm{~g}$ a.i./ha of indaziflam in 2014 and 2015, whereas an application rate of $150 \mathrm{~g}$ a.i./ha was used for trees with $\mathrm{HM}$ and ST in 2016. All trees were irrigated about every 14 days with $7 \mathrm{~L}$ of water in 2014 and 2015, and $5 \mathrm{~L}$ in 2016. A water balance analysis determined the $\mathrm{ET}$ in different treatments in 2014 and 2015. Gas exchange parameters were measured before and after irrigation in 2015 and 2016. Photosynthetic rates in $C, H M, P F$, and $S T$ were consistently significantly lower before than after irrigation. PF and ST did not decrease the available water content of the soil because there was no significant difference in the volume of effluent, ET, and gas exchange parameters among the treatments. No herbicide injury symptoms and no influence on gas exchange parameters and ET were observed after using both application rates of indaziflam.
\end{abstract}

Pecan [Carya illinoinensis (Wangenh.) $\mathrm{K}$. Koch] is an important crop of southern New Mexico, USA. Appropriate management practices are required to maintain the quality and yield of pecan while conserving water resources (Andales et al., 2006; Deb et al., 2011; Wang et al., 2007). Garrot et al. (1993) reported that pecan trees subjected to moderate water stress before irrigation showed reduced yield, nut weight, and tree growth. Plant water stress is influenced by weather, soil water availability, and tolerance capacity of species. Deb et al. (2012) reported that the stem water potential of pecan trees decreased with decreasing soil moisture content and

\footnotetext{
Received for publication 6 Mar. 2017. Accepted for publication 11 May 2017.

The authors thank Bayer CropScience Research Triangle Park, NC, for supporting funding for this work. Authors also thank Nakayama endowment and New Mexico State University Agricultural Experiment Station.

${ }^{1}$ Corresponding author. E-mail: amgonz4@nmsu. edu.
}

increasing air temperature. Similarly, lower photosynthetic rate was observed in blue oak leaves (Quercus douglasii H. \& A.) in midsummer as a result of seasonal changes in soil water content and temperature $(\mathrm{Xu}$ and Baldocchi, 2003). A previous study reported that maximum ET in a flood-irrigated pecan orchard was observed after budbreak during early summer (Sammis et al., 2004). However, evaporation was accounted for most of the water lost from the soil until $50 \%$ budbreak.

Plant water stress as a result of water deficit lowers photosynthetic rate during the growing season. High vapor pressure deficit between the plant and atmosphere combined with low soil water availability promotes the decline in plant water potential and stomatal conductance, and subsequently reduces the photosynthetic rate and transpiration (Sassaki et al., 1997; Turner et al., 1985). In addition, poor soil drainage, which can reduce soil oxygen levels, can exacerbate the decline in photosynthetic rate for pecans (Kallestad et al., 2007; Sparks, 2005). An increase of intercellular $\mathrm{CO}_{2}$ concentration in pecan trees subjected to prolonged flooding leads to decreases in photosynthetic rates (Kallestad et al., 2007).

Soil tillage practices have an important influence on soil hydraulic properties (Shukla et al., 2003; Strudley et al., 2008). Schwen et al. (2011) evaluated the impact of conventional, reduced, and no-tillage on the soil hydraulic properties and found greater bulk density, as result of natural compaction, and soil moisture content for no-tillage. Similarly, Shipitalo et al. (2000) reported higher macropore flow in no-tillage than conventional tillage. Macropores play an important role in the movement and distribution of water through the soil profile, as well as ecological interactions such as plant and soil relationship (Beven and Germann, 1982; Kramer and Boyer, 1995). Several studies have reported deeper than expected herbicide leaching through preferential flow channels (Flury et al., 1995; Rao et al., 1974; Shukla, 2014).

The correct use of agrochemicals applied for crop protection is beneficial for controlling crop pests, minimizing the entry of agrochemicals into water resources, and avoiding crop damage. Previous studies reported that the application of fungicides and insecticides temporarily reduced the photosynthetic rate of pecan under greenhouse and field conditions (Wood et al., 1984, 1985). Therefore, inappropriate application of pesticides could significantly reduce the tree energy reserves affecting the productivity of pecans (Wood et al., 1985). Indaziflam is a cellulose biosynthesis inhibitor registered with Environmental Protection Agency in 2012 and is used for preemergence control of annual grass and broadleaf weeds. Indaziflam is a new herbicide, and there is limited information available on its fate and transport under laboratory and field conditions (González-Delgado et al., 2017; Guerra et al., 2014; Trigo et al., 2014). Information on phytotoxicity effects of indaziflam on pecan is especially limited (González-Delgado et al., 2015). It is important to monitor the influence of indaziflam application, soil, and irrigation management practices on pecan ET and photosynthetic rates in arid regions with limited water resources because of their vital influence on quality and yield of pecan. The objectives of this study were to evaluate the effect of soil surface manipulation and indaziflam application on ET, gas exchange parameters of pecan trees, and phytotoxicity effects of indaziflam on pecan trees.

\section{Materials and Methods}

Surface soil conditions. This greenhouse study started in July 2014 and was continued until Nov. 2016 at the New Mexico State University's Fabian Garcia Science Center in Las Cruces, NM. The greenhouse was equipped with an exhaust, evaporative cooler pads on the east side, a heating system, and an automatic temperature control unit. In 2014, 
2-year-old pecan trees of the variety "Wichita" (Archer Farms, Inc., Las Cruces, NM) were planted in $0.035 \mathrm{~m}^{3}$ pots with an inner diameter and height of $36 \mathrm{~cm}$. Before tree planting, holes on the bottom of empty pots were covered with metal mesh to prevent soil loss. A 5-cm layer of gravel was placed on the bottom of the pots to facilitate free drainage. Sandy loam soil was air-dried and sieved through a 2-mm sieve. The organic matter content $(1.5 \pm 0.2 \%)$ and $\mathrm{pH}(8.4 \pm 0.08)$ of the sandy loam soil were determined using the loss on ignition method and a 1:1 soil to water ratio with a $\mathrm{pH}$ meter, respectively. Pots were subsequently packed with a $10-\mathrm{cm}$ layer of sandy loam soil, a pecan tree was placed at the center of the pot and sandy loam soil was packed around it.

Three different soil surface manipulations were created in 18 pots. A set of six trees were planted in pots with a HM, another six with PF channels open to the soil surface, and the remaining pots with the combination of preferential flow channels and shallow tillage up to $5 \mathrm{~cm}$ depth from soil surface (ST). Preferential flow channels were created by placing four $0.64-\mathrm{cm}$ diameter wooden sticks at opposite sides of the pots at a 45 degree angle toward the roots. The lower ends of the wooden sticks were near the cluster of roots at $\approx 17 \mathrm{~cm}$ depths and were left for 2 weeks to allow for stabilization of preferential flow channels. Preferential flow channels were intended to facilitate indaziflam and water movement toward the roots. After 2 weeks, the wooden sticks were removed from the pots, and the soil surface up to a $5 \mathrm{~cm}$ depth was manually tilled to interrupt the connection of the preferential flow channels at the soil surface in 6 of the 12 pots (ST treatment). The PF channels were created because injury to some pecan trees of the variety "Wichita" was reported in some orchards treated with indaziflam. It was widely hypothesized that indaziflam movement toward roots via PF channels caused the injury. Three additional trees planted in HM were used as control (not treated with indaziflam).

The trees were arranged using a completely randomized design with replications. During the study, trees were irrigated about every $14 \mathrm{~d}$ with $7 \mathrm{~L}\left(0.007 \mathrm{~m}^{3}\right)$ of water and once a month with $2 \mathrm{~L}$ of water during the dormant period using a watering container.

Indaziflam application. A small hand pump sprayer was used to spray indaziflam at different application rates directly over the soil. Care was taken to contain the spray plumes within the pot and as far as possible to not cause contamination. Indaziflam was applied using an application rate of $50 \mathrm{~g}$ a.i./ha on 18 Aug. 2014 and 27 July 2015 when all trees had fully expanded leaves after the end of the dormant periods. This rate is slightly lower than field application rate considering the lower dissipation rate of herbicide in greenhouse than in the field. The pots were irrigated with $7 \mathrm{~L}$ of water after $24 \mathrm{~h}$ of indaziflam application and every 2 weeks until the end of the study. Plastic containers were placed below the pots to collect the leachate after irrigation for water balance analysis (below). Necrosis of leaves and varying trunk injuries were herbicide injury symptoms observed in two pecan orchards located in Arizona and New Mexico 3-4 months after indaziflam application (González-Delgado et al., 2015). Therefore in this study, trees were evaluated visually for injury symptoms because of indaziflam after the applications. A visual evaluation for the development of necrotic tissue in the leaves was performed weakly until the dormant period. At the end of the dormant period, the trees were evaluated visually for injury symptoms again. On 25 July 2016, only HM and ST pots were treated with $150 \mathrm{~g}$ a.i./ha of indaziflam and irrigated with $5 \mathrm{~L}$ of water $48 \mathrm{~h}$ after indaziflam application. The amount of irrigated water was reduced, whereas the applied indaziflam rate was three times greater than the rate used in 2014 and 2015. No leachate was observed in the plastic containers after irrigation; therefore, pecan root exposure to indaziflam was higher in 2016 compared with the previous years. The aphids were treated with soap solution in 2014, Sivanto (Propylene carbonate) in 2015, and Admire Pro (Imidacloprid) in 2016.

Water balance. A water balance analysis was conducted to determine the ET in 2014 and 2015 . The change in storage $(\Delta S)$ was obtained from soil water content measured using Hydra Probes (Stevens Water Monitoring System, Inc., Portland, OR) at 12 and $22 \mathrm{~cm}$ depths from the soil surface. The total depth of irrigation water (I), depth of deep percolation, and $\Delta \mathrm{S}$ were used to determine the ET using Eq. [1] (Shukla, 2014).

$$
\mathrm{ET}=\mathrm{P}+\mathrm{I}-\mathrm{DP}-\Delta \mathrm{S}-\mathrm{RO}
$$

There were no precipitation $(\mathrm{P})$ and runoff (RO) because the trees were grown in a pot inside the greenhouse.

On 5 Nov. 2014, 10 Nov. 2015, and 2 Nov. 2016, trees were moved to an outside facility to induce the dormancy stage. During the dormancy stage, trees were irrigated with $2 \mathrm{~L}$ of water, and no effluent came out of the pot bottom after irrigation. By 6 May, the $25 \%$ budbreak (end of dormancy stage) in the trees was observed, and all the trees were moved back to the greenhouse.

Gas exchange parameters of pecan trees. Gas exchange parameters [(photosynthetic rate $\left(\mu \mathrm{mol} \cdot \mathrm{m}^{-2} \cdot \mathrm{s}^{-1}\right)$, intercellular $\mathrm{CO}_{2}$ concentration $\left(\mu \mathrm{mol} \cdot \mathrm{mol}^{-1}\right)$, vapor pressure deficit $(\mathrm{kPa})$, transpiration $\left(\mathrm{mmol} \cdot \mathrm{m}^{-2} \cdot \mathrm{s}^{-1}\right)$, stomatal conductance $\left(\mathrm{mol} \cdot \mathrm{m}^{-2} \cdot \mathrm{s}^{-1}\right)$, leaf temperature $\left({ }^{\circ} \mathrm{C}\right)$, and relative humidity $\left.(\%)\right]$ were measured before and after irrigation using a LI-COR 6400-portable gas exchange system (LI-COR Biosciences, Inc, Lincoln, NE). The LI-COR 6400-portable gas exchange system was adjusted at 400 $\mu \mathrm{mol} \cdot \mathrm{mol}^{-1}$ for both control reference $\mathrm{CO}_{2}$ and flow rate. Gas exchange parameters were measured between 11:00 AM and 2:00 PM about every $15 \mathrm{~d}$ from 13 July to 9 Nov. 2015 and from 12 July to 24 Sept. 2016. No data were collected between 21 Aug. and
8 Oct. 2015 because of adverse weather conditions and unavailability of the LI-COR 6400-portable gas exchange system. Photosynthetic active radiation was consistently between 998 and $1000 \mu \mathrm{mol} \cdot \mathrm{m}^{-2} \cdot \mathrm{s}^{-1}$ using the 6400-02B light source. Measurements were made on fully expanded leaves to cover the entire chamber of the portable gas exchange system on sunny days. One-way analysis of variance was performed to determine the difference in ET, effluent, and gas exchange parameters among treatments using SAS 9.2 (SAS Institute Inc., Cary, NC).

\section{Results and Discussion}

The average cumulative effluent from the pots of the C, HM, PF, and ST treatments ranged from $3.51 \pm 0.65$ to $7.73 \pm 2.2 \mathrm{~cm}$ in 2014 and from $6.64 \pm 0.8$ to $8.85 \pm 1.2 \mathrm{~cm}$ in 2015 (Fig. 1A). For both years, HM had the highest cumulative volume of effluent compared with the $\mathrm{C}, \mathrm{PF}$, and ST treatments. However, no significant differences in leachate volumes were seen among the treatments.

Macropores are reported to increase deep percolation (Beven and Germann, 1982; Mori and Hirai, 2014; Shipitalo et al., 2000; Zhou et al., 2012). In this study, the absence or presence of PF channels did not show an increase on the cumulative volume of effluent. No increases in the deep percolation in the PF and ST treatments could be due to the PF channels being only up to $17 \mathrm{~cm}$ depth from surface, smaller total volume of PF channels, likely collapse of the PF channels, and predominant lateral infiltration into the soil matrix. Mori and Hirai (2014) reported that empty macropores collapsed during the infiltration process after conducting a solute transport experiment with and without fibrous materials in the macropores. Zhou et al. (2012) reported higher infiltration in soils with macropores open at the soil surface than those closed at the surface or no macropores.

Average cumulative ET values for the $\mathrm{C}$, $\mathrm{HM}, \mathrm{PF}$, and ST treatments ranged from $21 \pm$ 3.8 to $28 \pm 1.1 \mathrm{~cm}$ in 2014 and from $55 \pm 6.7$ to $75 \pm 2.4 \mathrm{~cm}$ in 2015 (Fig. 1B). Cumulative ET in 2015 was $\approx 3$ times greater than the cumulative ET in 2014 because six more ET measurements were included in the water balance analysis conducted in 2015 . The C and HM treatments had lower cumulative ET than PF and ST treatments; however, cumulative ET was not significantly different among the C, HM, PF, and ST treatments. Soil evaporation could have increased by the subsoil exposed to the atmosphere in plots with PF channels and tillage (Cattle, 1999).

$\mathrm{PF}$ flow channels were expected to increase pecan root exposure to indaziflam and cause phytotoxicity. However, no visual phytotoxicity effects on pecan trees were observed in 2014. Gas exchange parameters were also measured in 2015 to determine if they were influenced by the second indaziflam application (50 g a.i./ha). But no phytotoxicity effects were observed in 2015 also using an application rate of $50 \mathrm{~g}$ a.i./ha. 

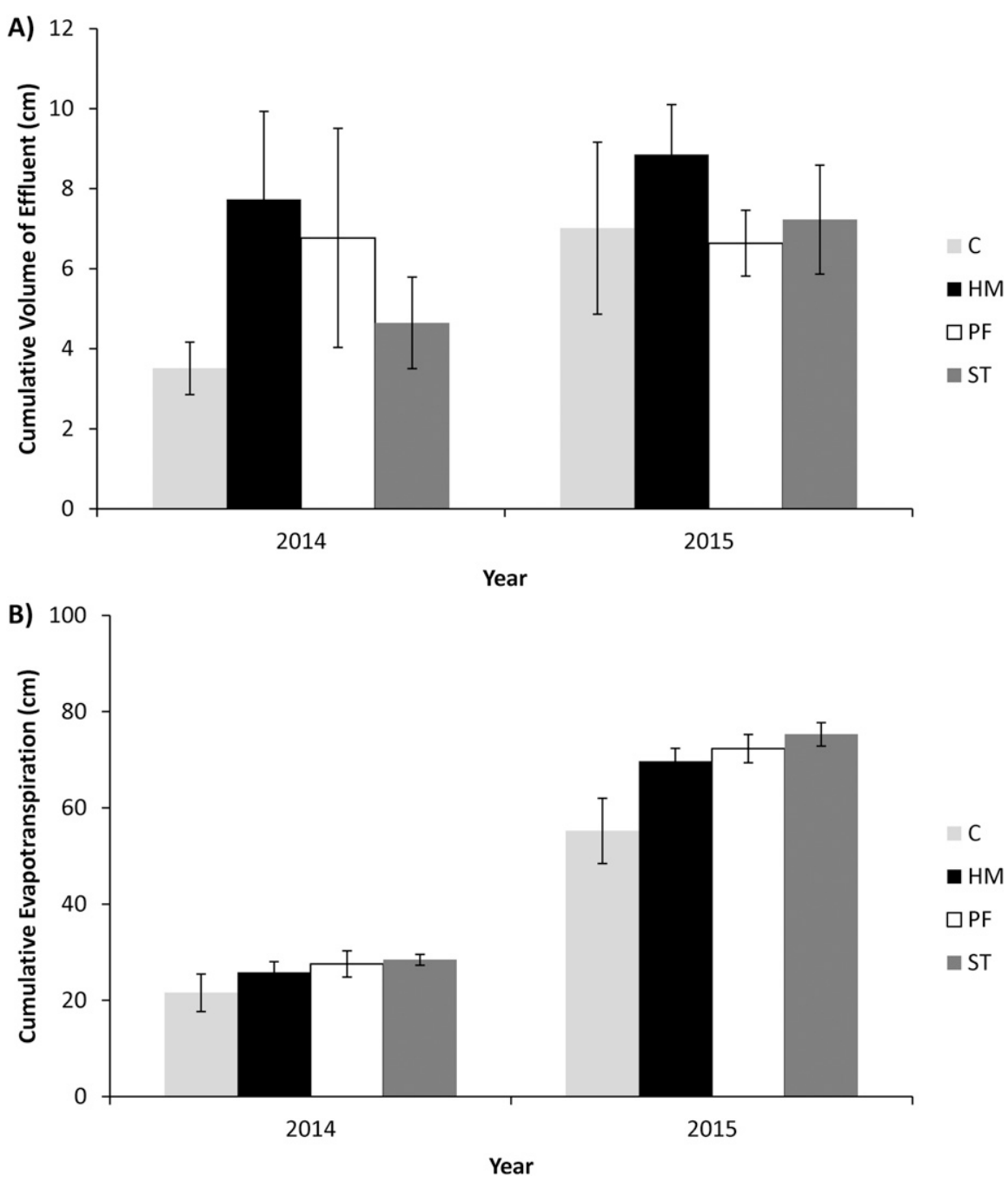

Fig. 1. Cumulative volume of effluent (A) and evapotranspiration (B) for control (C), homogeneous porous media (HM), preferential flow channels open at the soil surface (PF), and preferential flow channels with shallow tillage (ST) treatments for 2014 and 2015. Error bars represent standard error. Letters indicate significant difference among treatments based on the least significant difference test, $P<0.05$.

Therefore, in 2016, the pecan trees with HM and ST were treated with $150 \mathrm{~g}$ a.i./ha of indaziflam and irrigated with $5 \mathrm{~L}$ of water to prevent the leaching of indaziflam and increase in the exposure time. No phytotoxicity effects were seen even after increasing the application rate from 50 to $150 \mathrm{~g}$ a.i./ha and decreasing the leaching to zero. The absence of phytotoxicity effects could not explain the sporadic injury symptoms reported by González-Delgado et al. (2015) for an application rate of $73.1 \mathrm{~g}$ a.i./ha. GonzálezDelgado et al. (2015) reported that indaziflam was mostly detected in the unimpacted areas (no injury observed on pecan trees) of two pecan orchards 1 year after indaziflam application. A second field study reported that the percent mass recoveries of indaziflam could have been influenced by the organic matter content in the New Mexico pecan orchard where sporadic injury symptoms were observed in 2012 (González-Delgado et al., 2017). Percent mass recoveries of indaziflam were mostly higher in the unimpacted areas where the organic matter content was greater and $73.1 \mathrm{~g}$ a.i./ha during the second field study. The exact causes of the phytotoxicity observed after the first indaziflam applications in the two orchards are not fully known. However, root exposure to the indaziflam concentration which was much higher than the recommended rate likely caused injury.

The photosynthetic rate, transpiration, stomatal conductance, and relative humidity were higher after irrigation than before (Fig. 2). However, the opposite trend was observed for vapor pressure deficit from 13 July to 9 Nov. 2015 and from 12 July to 24 Sept. 2016 (Fig. 3). Studies have also reported increases in photosynthetic rate, transpiration rate, and stomatal conductance with irrigation (Asseng et al., 1998; Reed and Loik, 2016; Shem et al., 2009; Toselli et al., 2014; Xue et al., 2003). Increases in the relative humidity at the leaf surface after irrigation was the result of an increase of leaf water content (Fig. 3). Low soil moisture content increased vapor pressure deficit, decreased the leaf water potential, and promoted stomata closure (Comstock and Mencuccini, 1998; Gunderson et al., 2002; Turner et al., 1984). Under water stress conditions, the decrease in stomatal opening limits $\mathrm{CO}_{2}$ uptake that causes a reduction in photosynthetic activity and intercellular $\mathrm{CO}_{2}$ concentration (Anderson et al., 1995; Gunderson et al., 2002; Osakabe et al., 2014; Sharma et al., 2017; Turner et al., 1984). In contrast, some other studies reported an increase of the intercellular $\mathrm{CO}_{2}$ concentration in different tree species subjected to drought conditions (Brodribb, 1996; Kubiske et al., 1996). In this study, no clear trends in intercellular $\mathrm{CO}_{2}$ concentrations were observed for treatments $\approx 14 \mathrm{~d}$ after the previous irrigation in 2015 and 2016. Higher intercellular $\mathrm{CO}_{2}$ concentrations with increasing water stress were observed in some treatments before irrigation in 2015 on 13 July, 27 July, and 19 Oct., and also in 2016 on 26 July, 10 Aug., and 22 Sept. These could be explained by the reduction of carboxylation efficiency in the photosynthetic apparatus (Farquhar and Sharkey, 1982; Gomes et al., 2004). In 2015, leaf temperature did not show a clear trend with increasing water stress, but leaf temperature values were consistently higher $1 \mathrm{~d}$ before irrigation during 2016 (Fig. 3).

Photosynthetic rates $1 \mathrm{~d}$ before irrigation corresponded to the time of maximum water stress. Mostly, these values did not significantly decrease after indaziflam application on 27 July 2015 and 25 July 2016 and remained consistent with those collected before the herbicide applications. The data suggested that indazifam applications had no permanent effects on gas exchange parameters, except on 12 Aug. 2016 when photosynthetic rate was lower than expected. The reduction in the photosynthetic rate was most likely the result of treating the leaves of the pecan trees with an insecticide "Admire Pro" (Imidacloprid) on 8 Aug. 2016 for aphid control. It was observed that the leaves were 
A)

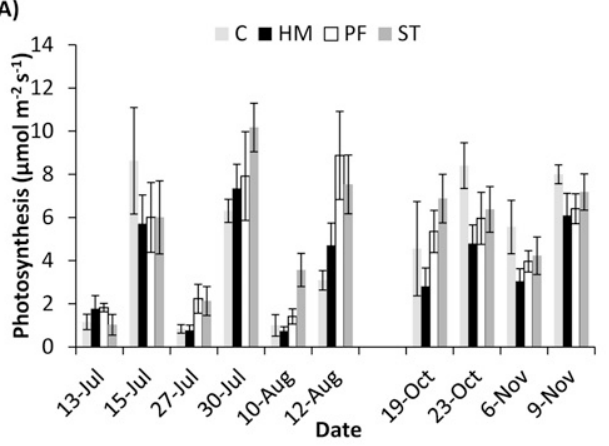

C)

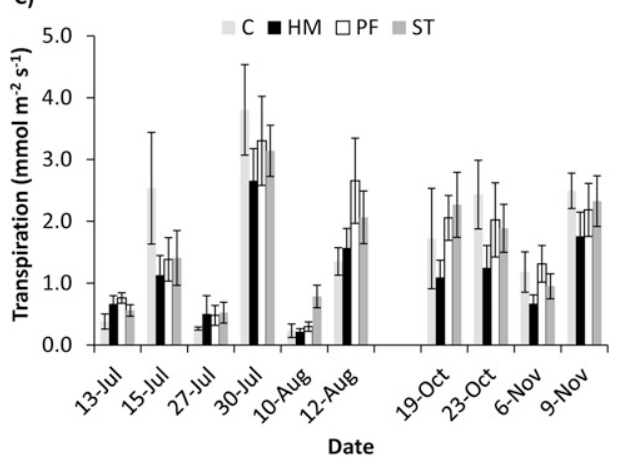

E)

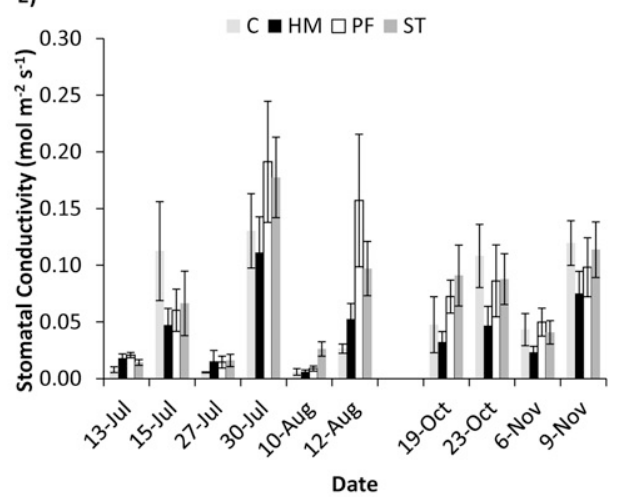

G)

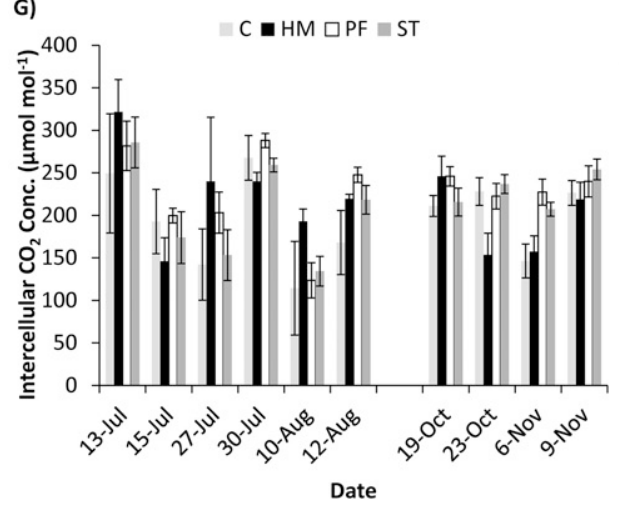

B)
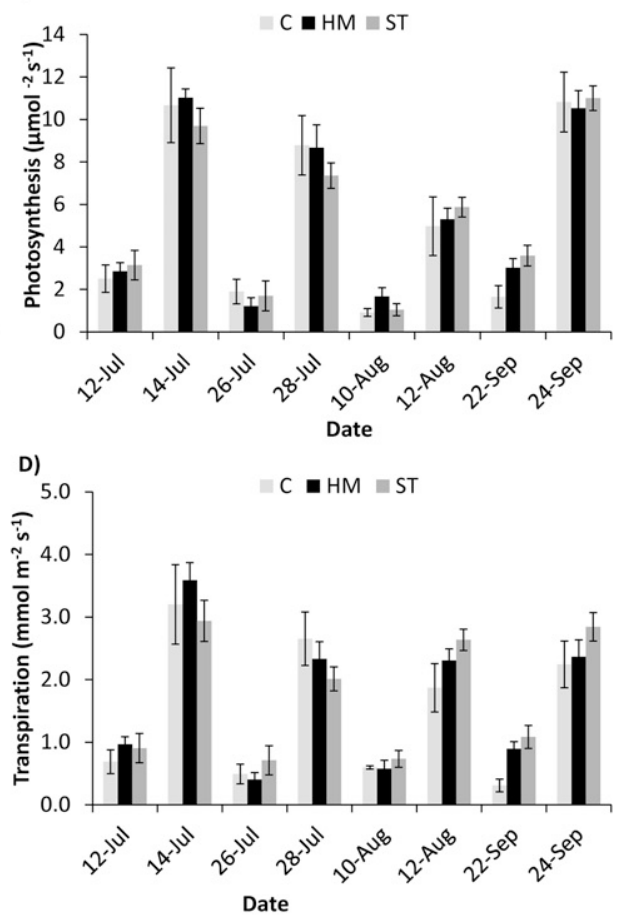

F)

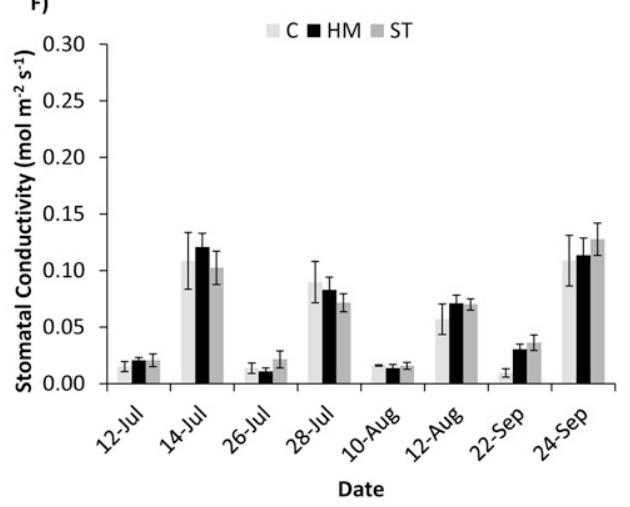

H)

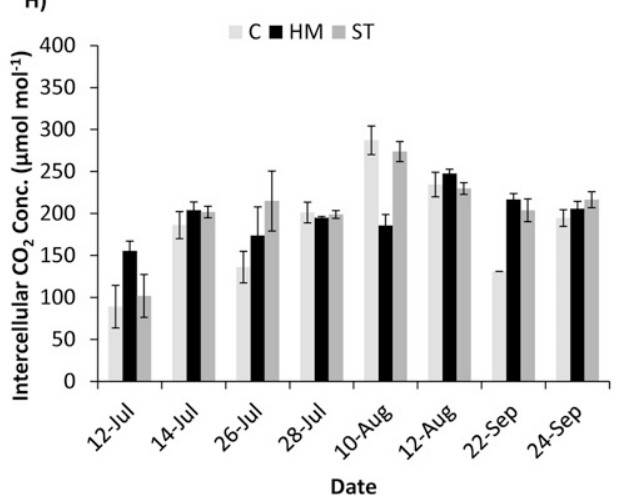

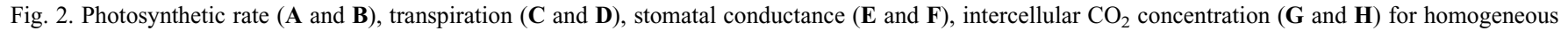
porous media (HM), preferential flow channels open at the soil surface (PF) and preferential flow channels with shallow tillage (ST) treatments in 2015 and for control (C), HM, and preferential flow channels with ST treatments in 2016. Error bars represent standard error. Letters indicate significant difference among treatments based on the least significant difference test, $P<0.05$.

covered by the protective coating of the insecticide for a longer period of time in 2016 . However, photosynthetic rate values recovered to levels before the insecticide application after 6 weeks (Fig. 2B). Although trees were also sprayed with Sivanto (Propylene carbonate) on 23 June 2015 for aphid control, but no reduction in photosynthetic rate was noted at that time. Wood et al. (1997) reported reductions in the photosynthetic rate of pecan for about $14 \mathrm{~d}$ after treating with an organosilicon surfactant. Generally, trees planted in indaziflam sprayed pots with $\mathrm{HM}, \mathrm{PF}$, and ST did not show a significant difference in the measured gas exchange parameters for most days. However, the photosynthetic rate was mostly lower in the HM treatment than in other treatments in 2015. Similarly, the 
A)

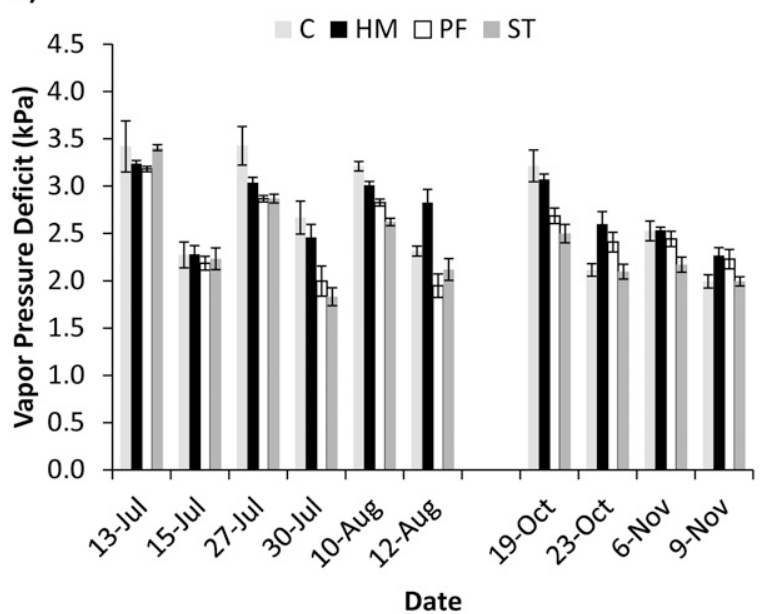

C)

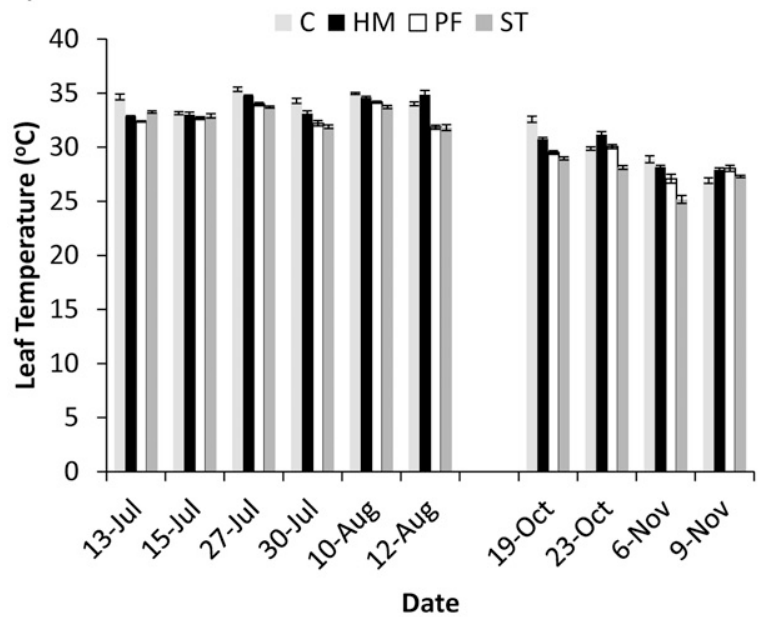

E)

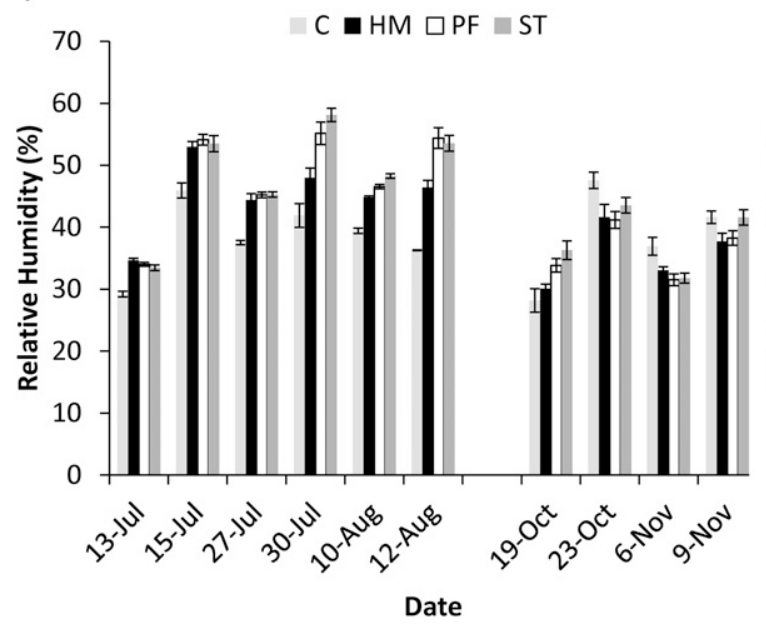

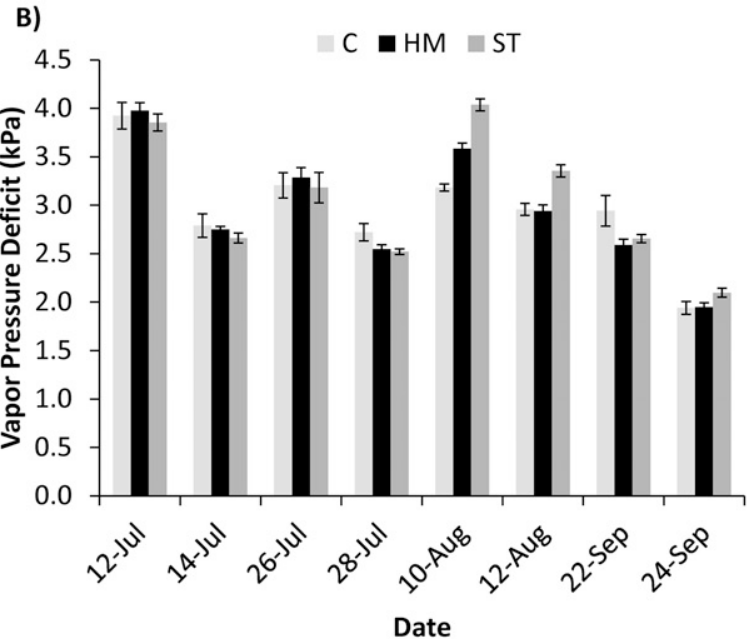

D)

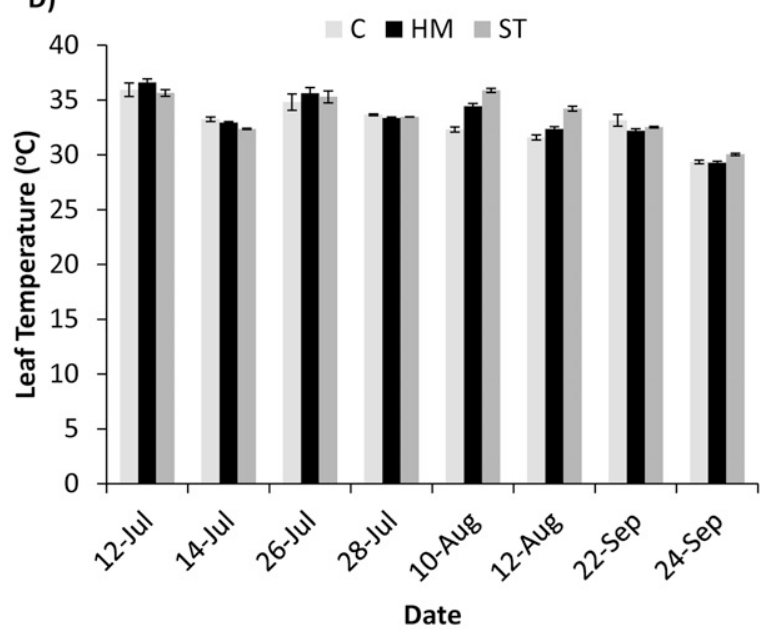

F)

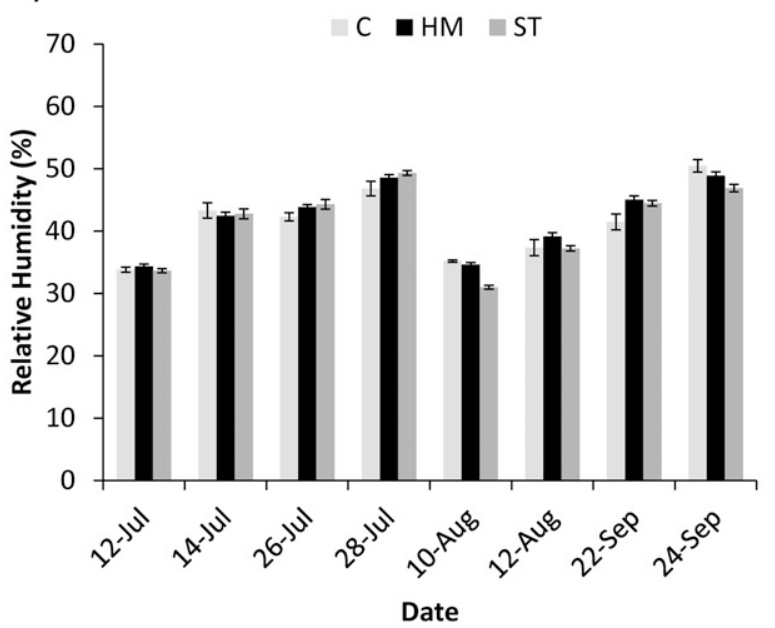

Fig. 3. Vapor pressure deficit (A and $\mathbf{B})$, leaf temperature (C and $\mathbf{D})$ and relative humidity ( $\mathbf{E}$ and $\mathbf{F})$ for homogeneous porous media (HM), preferential flow channels open at the soil surface (PF) and preferential flow channels with shallow tillage (ST) treatments in 2015 and for control (C), HM, and preferential flow channels with ST treatments in 2016. Error bars represent standard error. Letters indicate significant difference among treatments based on the least significant difference test, $P<0.05$.

photosynthetic rate was higher in ST than those with HM on 12 July, 12 Aug., 22 Sept., and 24 Sept. 2016. Greater plant biomass is reported in plots with artificial macropores than in control plots as a result of enhanced infiltration, nutrients, and oxygen (Mori et al., 2014). In this study, pots were filled with a sandy loam soil previously air-dried and sieved through a 2-mm sieve; therefore, the soil was free of organic debris and rocks that would normally influence the aeration process. The location of the preferential flow channels in pots with the PF and ST treatments might have contributed to a lower degree of stress as the result of greater aeration and easier root water uptake immediately after irrigation. Pecan trees are sensitive to poor soil drainage, and their productivity tends to decrease 
in areas under prolonged flooding conditions (Sparks, 2005).

\section{Conclusions}

There was no significant difference in the cumulative volume of effluent among the $\mathrm{HM}, \mathrm{PF}$, and ST treatments probably because of some degree of failure of the artificial preferential flow channels. Similarly, there was no significant difference in cumulative ET among treatments. Macropore channels did not seem to change soil water dynamics likely being present up to the partial soil depth. Less water stress was observed for pecan in ST and PF treatments likely because of quicker drainage and higher aeration than HM treatment. No phytotoxicity in pecan trees treated with 50 and $150 \mathrm{~g}$ a.i./ha of indaziflam suggested that indaziflam did not affect pecan trees subjected to water stress in this study under greenhouse conditions.

\section{Literature Cited}

Andales, A., J. Wang, T.W. Sammis, J.G. Mexal, L.J. Simmons, D.R. Miller, and V.P. Gutschick. 2006. A model of pecan tree growth for the management of pruning and irrigation. Agr. Water Mgt. 84:77-88.

Anderson, J.E., R.S. Nowak, K.E. Rasmuson, and N.L. Toft. 1995. Gas exchange and resourceuse efficiency of Leymus cinereus (Poaceae): Diurnal and seasonal responses to naturally declining soil moisture1. Amer. J. Bot. 82: 699-708.

Asseng, S., J.T. Ritchie, A.J.M. Smucker, and M.J. Robertson. 1998. Root growth and water uptake during water deficit and recovering in wheat. Plant Soil 201:265-273.

Beven, K. and P. Germann. 1982. Macropores and water flow in soils. Water Resour. Res. 18: 1311-1325.

Brodribb, T. 1996. Dynamics of changing intercellular $\mathrm{CO}_{2}$ concentration (ci) during drought and determination of minimum functional ci. Plant Physiol. 111:179-185.

Cattle, S.R. 1999. Efficacy of perforating the soil to capture and store rain during fallow in dry regions. Eur. J. Soil Sci. 50:481-487.

Comstock, J. and M. Mencuccini. 1998. Control of stomatal conductance by leaf water potential in Hymenoclea salsola ( $\mathrm{T}$. and G.), a desert subshrub. Plant Cell Environ. 21:10291038.

Deb, S.K., M.K. Shukla, and J.G. Mexal. 2011. Numerical modeling of water fluxes in the root zone of a mature pecan orchard. Soil Sci. Soc. Amer. J. 75:1667-1680.

Deb, S.K., M.K. Shukla, and J.G. Mexal. 2012. Estimating midday leaf and stem water potentials of mature pecan trees from soil water content and climatic parameters. HortScience 47:907-916.

Farquhar, G.D. and T.D. Sharkey. 1982. Stomatal conductance and photosynthesis. Annu. Rev. Plant Physiol. 33:317-345.

Flury, M., J. Leuenberger, B. Studer, and H. Fluhler. 1995. Transport of anions and herbicides in a loamy and a sandy field soil. Water Resour. Res. 31:823-835.

Garrot, D.J., Jr., M.W. Kilby, D.D. Fangmeier, S.H. Husman, and A.E. Ralowicz. 1993. Production, growth, and nut quality in pecans under water stress based on the crop water stress index. J. Amer. Soc. Hort. Sci. 118:694-698.

Gomes, M.M.A., A.M.M.A. Lagôa, C.L. Medina, E.C. Machado, and M.A. Machado. 2004. Interactions between leaf water potential, stomatal conductance and abscisic acid content of orange trees submitted to drought stress. Braz. J. Plant Physiol. 16:155-161.

González-Delgado, A.M., J. Ashigh, M.K. Shukla, and R. Perkins. 2015. Mobility of indaziflam influenced by soil properties in a semi-arid area. PLoS One 10(5):E0126100, doi: 10.1371/ journal.pone. 0126100 .

González-Delgado, A.M., J. Ashigh, M.K. Shukla, and R. Perkins. 2017. Effect of application rate and irrigation on the movement and degradation of indaziflam. J. Environ. Sci. 51:111-119.

Guerra, N., A.M. Oliveira Neto, R.S. Jr. Oliveira, J. Constantin, and H.K. Takano. 2014. Sensibility of plant species to herbicides aminocyclopyrachlor and indaziflam. Planta Daninha 32:609617.

Gunderson, C.A., J.D. Sholtis, S.D. Wullschleger, D.T. Tissue, P.J. Hanson, and R.J. Norby. 2002. Environmental and stomatal control of photosynthetic enhancement in the canopy of a sweetgum (Liquidambar styraciflua L.) plantation during 3 years of $\mathrm{CO}_{2}$ enrichment. Plant Cell Environ. 25:379-393.

Kallestad, J.C., T.W. Sammis, J.G. Mexal, and V. Gutschick. 2007. The impact of prolonged flood-irrigation on leaf gas exchange in mature pecans in an orchard setting. Intl. J. Plant Prod. 2:163-178.

Kramer, P.J. and J.S. Boyer. 1995. Water relations of plants and soils. Academic Press, San Diego, CA.

Kubiske, M.E., M.D. Abrams, and S.A. Mostoller. 1996. Stomatal and nonstomatal limitations of photosynthesis in relation to the drought and shade tolerance of tree species in open and understory environments. Trees 11:76-82.

Mori, Y., A. Fujihara, and K. Yamagishi. 2014 Installing artificial macropores in degraded soils to enhance vertical infiltration and increase soil carbon content. Prog. Earth Planet. Sci., doi: 10.1186/s40645-014-0030-5.

Mori, Y. and Y. Hirai. 2014. Effective vertical solute transport in soils by artificial macropore system. J. Hazard. Toxic Radioact., doi: 10.1061 (ASCE)HZ.2153-5515.0000192.

Osakabe, Y., K. Osakabe, K. Shinozaki, and L.P. Tran. 2014. Response of plants to water stress. Front. Plant Sci. 5:1-8.

Rao, P.S.C., R.E. Green, V. Balasubramanian, and Y. Kanehiro. 1974. Field study of solute movement in a highly aggregated oxisol with intermittent flooding. II Picloram. J. Environ. Qual. 3:197-202.

Reed, C.C. and M.E. Loik. 2016. Water relations and photosynthesis along an elevation gradient for Artemisia tridentata during an historic drought. Oecologia 181:65-76.

Sammis, T.W., J.G. Mexal, and D. Miller. 2004. Evapotranspiration of flood-irrigated pecans. Agr. Water Mgt. 69:179-190.

Sassaki, R.M., E.C. Machado, A.M.M.A. Lagôa, and G.M. Felippe. 1997. Effect of water deficiency on photosynthesis of Dalbergia miscolobium Benth., a cerrado tree species. Rev. Bras. Fisiol. Vegetal 9:83-87.

Schneider, J.G., J.B. Haguewood, E. Song, X. Pan, J.M. Rutledge, B.J. Monke, D.F. Myers, S.H Anderson, M.R. Ellersieck, and X. Xiong. 2015. Indaziflam effect on bermudagrass (Cynodondactylon L. pers.) shoot growth and root initiation as influenced by soil texture and organic matter. Crop Sci. 55:429-436.
Schwen, A., G. Bodner, P. Scholl, G.D. Buchan, and W. Loiskandl. 2011. Temporal dynamics of soil hydraulic properties and the waterconducting porosity under different tillage. Soil Tillage Res. 113:89-98.

Sharma, P., M.K. Shukla, P. Bosland, and R. Steiner. 2017. Soil moisture sensor calibration, actual evapotranspiration and crop coefficients for deficit irrigated greenhouse chile. Agr. Water Mgt. 179:81-91.

Shukla, M.K. 2014. Soil physics an Introduction. CRC Press. Boca Raton, FL, p. 458.

Shem, K., M. Catherine, and C. Ong. 2009. Gas exchange responses of Eucalyptus, C. africana and $G$. robusta to varying soil moisture content in semi-arid (Thika) Kenya. Agrofor. Syst. 75:239-249.

Shipitalo, M.J., W.A. Dick, and W.M. Edwards. 2000. Conservation tillage and macropore factors that affect water movement and the fate of chemicals. Soil Tillage Res. 53:167-183.

Shukla, M.K., R. Lal, L.B. Owens, and P. Unkefer. 2003. Land use and management impacts on structure and infiltration characteristics of soils in the North Appalachian Region of Ohio. Soil Sci. 168(3):167-177.

Sparks, D. 2005. Adaptability of pecan as a species. HortScience 40:1175-1189.

Strudley, M.W., T.R. Green, and J.C. Ascough, II. 2008. Tillage effects on soil hydraulic properties in space and time: State of the science. Soil Tillage Res. 99:4-48.

Toselli, M., G. Marcolini, J.A. Flore, and L. Lombardini. 2014. Leaf assimilation, carbon translocation and root respiration in 'budagovski 9' apple cuttings grown in low soil moisture condition. Eur. J. Hort. Sci. 79:241-247.

Trigo, C., W.C. Koskinen, and R.S. Kookana. 2014. Sorption-desorption of indaziflam and its three metabolites in sandy soils. J. Environ. Sci. Health B 49(11):836-843.

Turner, N.C., E.D. Schulze, and T. Gollan. 1984. The responses of stomata and leaf gas exchange to vapour pressure deficits and soil water content I. species comparisons at high soil water contents. Oecologia 63:338-342.

Turner, N.C., E.D. Schulze, and T. Gollan. 1985. The responses of stomata and leaf gas exchange to vapour pressure deflcits and soil water content II. In the mesophytic herbaceous species Helianthus annuus. Oecologia 65:348-355.

Wang, J., T.W. Sammis, A.A. Andales, L.J. Simmons, V.P. Gutschick, and D.R. Miller. 2007. Crop coefficients of open-canopy pecan orchards. Agr. Water Mgt. 88:253-262.

Wood, B., T. Gottwald, and J. Payne. 1984. Influence of single applications of fungicides on net photosynthesis of pecan. Plant Dis. 68:427-428.

Wood, B., J. Payne, and T. Gottwald. 1985. Reduced leaf net photosynthesis of orchard grown pecan by pesticide sprays. Proc. Annu. Convention Southeastern Pecan Growers Assn. 8th, 69-72.

Wood, B., W.L. Tedders, and J. Taylor. 1997. Control of pecan aphids with an organosilicone surfactant. HortScience 32:1074-1076.

Xu, L. and D.D. Baldocchi. 2003. Seasonal trends in photosynthetic parameters and stomatal conductance of blue oak (Quercus douglasii) under prolonged summer drought and high temperature. Tree Physiol. 23:865-877.

Xue, Q., Z. Zhu, J.T. Musick, B.A. Stewart, and D.A. Dusek. 2003. Root growth and water uptake in winter wheat under deficit irrigation. Plant Soil 257:151-161.

Zhou, B.B., S. Li, Q.J. Wang, Y.L. Jiang, and Y. Li. 2012. Effects of macropore continuity on water movement and solute transport in a loessial soil. Austral. J. Crop Sci. 6:1024-1029. 